\title{
FAKTOR-FAKTOR YANG MEMPENGARUHI TERJADINYA RUPTURE PERINIUM DI KAMAR BESALIN RSUD IBNU SOETOWO BATURAJA KAB OKU TAHUN 2016
}

\author{
Yeviza Puspitasari, SKM., M.Kes \\ Program Studi Diploma III Kebidanan - STIKES AL-MA'ARIF BATURAJA
}

E-mail: yeviza.puspitasari1402@gmail.com

\begin{abstract}
ABSTRAK
Penduhuluan: Upaya penurunan AKI harus difokuskan pada penyebab langsung kematian ibu, yang terjadi $90 \%$ pada saat persalinan dan segera setelah persalinan, yaitu perdarahan $(28 \%)$, eklamsia $(24 \%)$, infeksi (11\%), komplikasi pueperium $8 \%$, partus macet $5 \%$, abortus $5 \%$, trauma obstetrik $5 \%$, emboli $3 \%$, dan lain-lain $11 \%$. Robekan jalan lahir merupakan penyebab kedua setelah atonia uteri. Rupture perineum dipengaruhi oleh beberapa faktor yaitu faktor maternal, faktor janin dan faktor penolong. Tujuan penelitian: Untuk mengetahui Hubungan Faktor-Faktor Yang Mempengaruhi Terjadinya Rupture Perineum Di Kamar Bersalin RSUD Dr. H. Ibnu Sutowo Baturaja Kabupaten Ogan Komering Ulu Tahun 2016. Metode penelitian: menggunakan metode survey analitik dengan pendekatan cross sectional. Populasi dalam penelitian ini adalah seluruh ibu yang melahirkan dikamar bersalin RSUD Dr. Ibnu Soetowo periode Januari - Februari 2016. Sampel penelitian menggunakan metode Simple Random sampling dan didapatkan 76 orang. Penelitian dilaksanakan di RSUD Dr. Ibnu Sutowo Baturaja Kabupaten Ogan Komering Ulu. Pengumpulan data melalui check list. Pengolahan data secara analisa univariat dan bivariat. Hasil penelitian: didapatkan hasil ada hubungan antara berat badan lahir dengan kejadian rupture perineum ( $p$ value 0,000 ), Jarak Kelahiran dengan kejadian rupture perineum ( $p$ value 0,000 ) dan Paritas dengan kejadian Rupture Perineum ( $p$ value 0,002).
\end{abstract}

Kata kunci : Rupture Perineum, Berat Badan Lahir, Jarak Kelahiran, Paritas

\section{ABSTRACT}

Introduction: Efforts to reduce MMR should be focused on the direct cause of maternal death, which occurs 90\% during labor and immediately after delivery, namely bleeding (28\%), eclampsia (24\%), infection (11\%), complications of $8 \%$ pueperium, parturition traffic jam 5\%, abortion 5\%, obstetric trauma 5\%, embolism 3\%, etc. $11 \%$. Tearing of the birth canal is the second cause after uterine atony. Perineal rupture is influenced by several factors, namely maternal factors, fetal factors and helping factors. The purpose of this study: To determine the relationship of factors that influence the occurrence of rupture of the perineum in the delivery room of RSUD Dr. H. Ibnu Sutowo Baturaja Ogan Komering Ulu Regency in 2016. The research method: using analytic survey method with cross sectional approach. The population in this study were all mothers giving birth in the maternity hospital Dr. Ibnu Soetowo for the period January - February 2016. The research sample used the Simple Random Sampling method and found 76 people. The study was conducted at Dr. Ibnu Sutowo Baturaja Ogan Komering Ulu Regency. Data collection through check list. Univariate and bivariate analysis of data processing. Results: The results showed that there was a relationship between birth weight and the incidence of perineal rupture ( $p$ value $0,000)$, birth distance with perineal rupture event ( $p$ value 0,000$)$ and parity with perineum rupture ( $p$ value 0.002).

Keywords: Perineum Rupture, Birth Weight, Birth Distance, Parity 


\section{PENDAHULUAN}

Setiap tahun sekitar 160 juta perempuan di seluruh dunia mengalami kehamilan. Sebagian besar kehamilan ini aman. Namun, sekitar 15\% menderita komplikasi berat, dengan sepertiganya merupakan komplikasi yang mengancam jiwa ibu. Komplikasi ini mengakibatkan kematian lebih dari setengah juta ibu setiap tahun. Dari jumlah ini diperkirakan 90\% terjadi di Asia dan Afrika subsahara, $10 \%$ di negara berkembang lainnya, dan kurang dari $1 \%$ di negara-negara maju. Di beberapa negara resiko kematian ibu lebih tinggi dari 1 dalam 10 kehamilan, sedangkan di negara maju resiko ini kurang dari 1 dalam 6.000 kehamilan (Prawirohardjo, 2011).

WHO 1997 pada Hari Kesehatan Sedunia menyatakan Safe Motherhood merupakan upaya global untuk menurunkan kematian dengan slogan Making Pregnancy Safer (MPS). Komitmen dari MPS ini adalah penurunan AKI dari tahun 1990 menjadi $50 \%$ pada tahun 2000 dan selanjutnya penurunan $50 \%$ lagi di tahun 2015 dengan penurunan AKI seluruhnya $75 \%$ menjadi $115 / 100.000$ kelahiran hidup dan AKB menjadi 35/1.000 kelahiran hidup dalam tahun 1990-2015 (Prawirohardjo, 2011).

Hasil Survei Dasar Kesehatan Indonesia (SDKI) 2012 menunjukan ada persoalan dalam pencapaian target penurunan $\mathrm{AKI}, \mathrm{AKB}$ dan AKABA di Indonesia. Kematian lbu melonjak sangat signifikan menjadi 359/100.000 kelahiran hidup atau mengembalikan pada kondisi tahun 1997. Ini berarti kesehatan ibu justru mengalami kemunduran selama 15 tahun. Pada tahun 2007, AKI di Indonesia sebenarnya telah mencapai 228/100.000 kelahiran hidup (Saputra, 2013).

Menurut hasil berbagai survei, tinggi rendahnya Angka Kematian Ibu (AKI) dan Angka Kematian Bayi (AKB) disuatu Negara dapat dilihat dari kemampuan untuk memberikan pelayanan obstetrik yang bermutu dan menyeluruh. Dari hasil survei yang dilakukan AKI telah menunjukkan penurunan dari waktu ke waktu, namun demikian upaya untuk mewujudkan target tujuan pembangunan millenium masih membutuhkan komitmen dan usaha keras yang terus menerus (Rosmawar, 2013).

Upaya penurunan AKI harus difokuskan pada penyebab langsung kematian ibu, yang terjadi $90 \%$ pada saat persalinan dan segera setelah pesalinan, yaitu perdarahan (28\%), eklamsia (24\%), infeksi (11\%), komplikasi pueperium $8 \%$, partus macet $5 \%$, abortus $5 \%$, trauma obstetrik $5 \%$, emboli $3 \%$, dan lain-lain 11\% (Rosmawar, 2013).

Robekan jalan lahir merupakan penyebab kedua setelah atonia uteri. Hal ini sering terjadi pada primipara karena pada saat proses persalinan tidak mendapat tegangan yang kuat sehingga menimbulkan robekan pada perineum. Luka-luka biasanya ringan tapi kadang juga terjadi luka yang luas sehingga dapat menimbulkan perdarahan yang dapat membahayakan jiwa ibu (Rosmawar, 2013).

Rupture perineum adalah robeknya perineum pada saat janin lahir. Rupture perineum terjadi pada hampir semua persalinan pertama dan tidak jarang juga pada persalinan berikutnya. Robekan dapat terjadi di bagian dalam serviks atau vagina, atau bagian luar genital atau perineum atau anus. Robekan ini dapat dihindarkan atau dikurangi dengan menjaga jangan sampai dasar panggul dilalui oleh kepala janin dengan cepat. Sebaliknya kepala janin yang akan lahir jangan ditahanterlampau kuat dan lama, karena akan menyebabkan asfiksia dan perdarahan dalam tengkorak janin, dan melemahkan otot-otot dan fasia pada dasar panggul karena diregangkan terlalu lama (Prawirohardjo, 2011). 
Hasil studi dari Pusat Penelitian dan Pengembangan (Puslitbang) Bandung, yang melakukan penelitian dari tahun 2009-2010 pada beberapa Propinsi di Indonesia didapatkan bahwa satu dari lima ibu bersalin yang mengalami rupture perineum akan meninggal dunia dengan persentase $21,74 \%$. Prevalensi ibu bersalin yang mengalami rupture perineum di Indonesia pada golongan umur 25-30 tahun yaitu $24 \%$ sedang pada ibu bersalin usia 32-39 tahun sebesar 62\% (Endriani, 2012).

Robekan jalan lahir selalu memberikan perdarahan dalam jumlah yang bervariasi banyaknya. Sumber perdarahan dapat berasal dari perineum,vagina, serviks, dan robekan uterus (Ruptura Uteri). Robekan jalan lahir banyak dijumpai pada pertolongan persalinan oleh dukun. Pertolongan persalinan oleh tenaga kesehatan dengan risiko rendah mempunyai komplikasi ringan sehingga dapat menurunkan Angka Kematian Ibu (AKI) maupun perinatal (Manuaba, 2010).

Terjadinya rupture perineum disebabkan oleh faktor ibu sendiri (yang mencakup paritas, jarak kelahiran dan berat badan lahir), riwayat persalinan yang mencakup ekstraksi cunam, ekstraksi vakum dan episiotomi.

Paritas adalah jumlah anak yang dilahirkan oleh seseorang ibu baik hidup maupun mati. Paritas mempunyai pengaruh terhadap kejadian rupture perineum. Pada ibu dengan paritas satu atau ibu primipara memiliki risiko lebih besar untuk mengalami robekan perineum daripada ibu dengan paritas lebih dari

\section{METODE PENELITIAN}

Jenis penelitian ini menggunakan metode survey analitik dengan pendekatan cross sectional, dimana data yang menyangkut variabel independen yaitu Berat Badan Lahir, Jarak Kelahiran, satu. Hal ini dikarenakan karena jalan lahir yang belum pernah dilalui oleh kepala bayi sehingga otot-otot perineum belum meregang (Rosmawar, 2013).

Selain itu jarak kelahiran kurang dari dua tahun tergolong risiko tinggi karena dapat menimbulkan komplikasi pada persalinan. Serta persalinan terdahulu yang mengalami robekan perineum derajat tiga atau empat, sehingga proses pemulihan belum sempurna dan robekan perineum dapat terjadi (Rosmawar, 2013).

Faktor selanjutnya ialah berat badan janin dapat mengakibatkan terjadinya rupture perineum yaitu pada berat badan janin diatas 3500 gram, karena risiko trauma partus melalui vagina seperti distosia bahu dan kerusakan jaringan lunak pada ibu.

Berdasarkan data awal yang diperoleh di Kamar Bersalin RSUD Dr. $\mathrm{H}$. Ibnu Sutowo, pada tahun 2013 jumlah ibu yang mengalami rupture perineum sebanyak 113 (6,1\%) kasus dari 1849 persalinan, dan pada tahun 2014 jumlah ibu yang mengalami rupture perineum sebanyak 62 (3,6\%) kasus dari 1725 persalinan. Sedangkan pada tahun 2015 jumlah ibu yang mengalami rupture perineum sebanyak 117 (6,8\%) kasus dari 1724 persalinan. Dan berdasarkan survey awal yang dilakukan pada bulan Februari Tahun 2016 jumlah ibu yang mengalami rupture perineum pada bulan JanuariFebruari 2016 sebanyak 41 (11,3\%) kasus dari 362 ibu yang melahirkan.

Paritas serta variabel dependen yaitu Rupture Perineum Di Kamar Bersalin RSUD Dr. H. Ibnu Sutowo Baturaja Kabupaten Ogan Komering Ulu dikumpulkan dalam waktu bersamaan. 
Populasi dalam penelitian ini adalah seluruh ibu yang melahirkan di Kamar Bersalin RSUD Dr. H. Ibnu Sutowo Baturaja Kabupaten OKU periode Januari - Februari Tahun 2016 sebanyak 362 persalinan di Kamar Bersalin RSUD Dr. H. Ibnu Sutowo Baturaja

Sampel berasal dari ibu-ibu yang melahirkan pada bulan Januari sampai dengan Mei 2016 di Kamar Bersalin RSUD Dr. H. Ibnu Sutowo dengan menggunakan random sampling

\section{HASIL PENELITIAN}

Analisa yang dilakukan untuk melihat hubungan antara berat badan lahir, jarak kelahiran dan paritas dengan variabel dependen rupture perineum, menggunakan uji statistik chi-squre dan sistem komputerisasi dengan batas kemaknaan $\leq 0,05$ dan derajat kepercayaan 95\%. Dikatakan adanya hubungan bermakna bila $p$ value $\leq 0,05$ dan apabila $p$ value $>0,05$ maka kedua variabel tersebut dikatakan tidak ada hubungan bermakna.

\section{Berat Badan lahir}

Untuk mengetahui hubungan berat badan lahir dengan kejadian rupture perineum dilakukan uji chi square

Tabel. 1

Hubungan Berat Badan Lahir Dengan Kejadian Rupture Perineum Di Kamar Bersalin RSUD Dr. H. Ibnu Sutowo Baturaja Tahun 2016

\begin{tabular}{lccccccc}
\hline \multicolumn{7}{c}{ Berat Badan lahir } \\
\hline Rupture perineum & Bayi Besar & Bayi Cukup & Jumlah & $p$ value \\
& $\mathrm{f}$ & $\%$ & $\mathrm{f}$ & $\%$ & $\mathrm{f}$ & $\%$ & \\
\hline Ya & 48 & 81,4 & 11 & 18,6 & 59 & 100 & \\
\hline Tidak & 4 & 23,5 & 13 & 76,5 & 17 & 100 & 0,000 \\
\hline Jumlah & 52 & 68,4 & 24 & 31,6 & 76 & 100 & \\
\hline
\end{tabular}

Berdasarkan tabel 5.5 didapatkan bahwa dari 59 responden yang mengalami rupture perineum terdapat 48 responden $(81,4 \%)$ dengan berat badan lahir bayi besar dan 11 responden (18,6\%) dengan berat badan lahir bayi cukup. Sedangkan dari 17 responden yang tidak mengalami rupture perineum terdapat 4 responden $(23,5 \%)$ dengan berat badan lahir bayi besar dan 13 responden (76,5\%) dengan berat badan lahir bayi cukup.
Dari hasil uji statistik chi-squre diperoleh $p$ value $0,000<0,05$ hal ini menunjukkan bahwa ada hubungan yang bermakna antara berat badan lahir dengan kejadian rupture perineum. Sehingga hipotesis terbukti secara statistik.

\section{Jarak Kelahiran}

Untuk mengetahui hubungan jarak kelahiran dengan kejadian rupture perineum dilakukan uji chi square 
Tabel. 2

\section{Hubungan Jarak Kelahiran Dengan Kejadian Rupture Perineum Di Kamar Bersalin RSUD Dr. H. Ibnu Sutowo Baturaja Tahun 2016}

\begin{tabular}{lccccccc}
\hline \multicolumn{7}{c}{ Jarak kelahiran } \\
\hline Rupture Perineum & \multicolumn{1}{c}{ Beresiko } & \multicolumn{2}{c}{ Tidak } & Jumlah & $p$ value \\
& \multicolumn{1}{c}{ Beresiko } & & & \\
\hline Ya & $\mathrm{f}$ & $\%$ & $\mathrm{f}$ & $\%$ & $\mathrm{f}$ & $\%$ & \\
\hline Tidak & 51 & 86,4 & 8 & 13,6 & 59 & 100 & \\
\hline Jumlah & 7 & 41,2 & 10 & 58,8 & 17 & 100 & 0,000 \\
\hline
\end{tabular}

Berdasarkan tabel. 2 didapatkan bahwa dari 59 responden yang mengalami rupture perineum terdapat 51 responden $(86,4 \%)$ dengan memiliki jarak kelahiran beresiko dan 8 responden $(13,6 \%)$ dengan memiliki jarak kelahiran tidak beresiko. Sedangkan dari 17 responden yang tidak mengalami rupture perineum terdapat 7 responden $(41,2 \%)$ dengan memiliki jarak kelahiran beresiko dan 10 responden $(58,8 \%)$ dengan memiliki jarak kelahiran tidak beresiko.
Dari hasil uji statistik chi-squre diperoleh $p$ value $0,000<0,05$ ini menunjukkan bahwa ada hubungan yang bermakna antara jarak kelahiran dengan kejadian rupture perineum. Sehingga hipotesis terbukti secara statistik.

\section{Paritas}

Untuk mengetahui paritas dengan kejadian rupture perineum dilakukan uji chi square

Tabel. 3

Hubungan Paritas Dengan Kejadian Rupture Perineum Di Kamar Bersalin RSUD Dr. H. Ibnu Sutowo Baturaja Tahun 2016

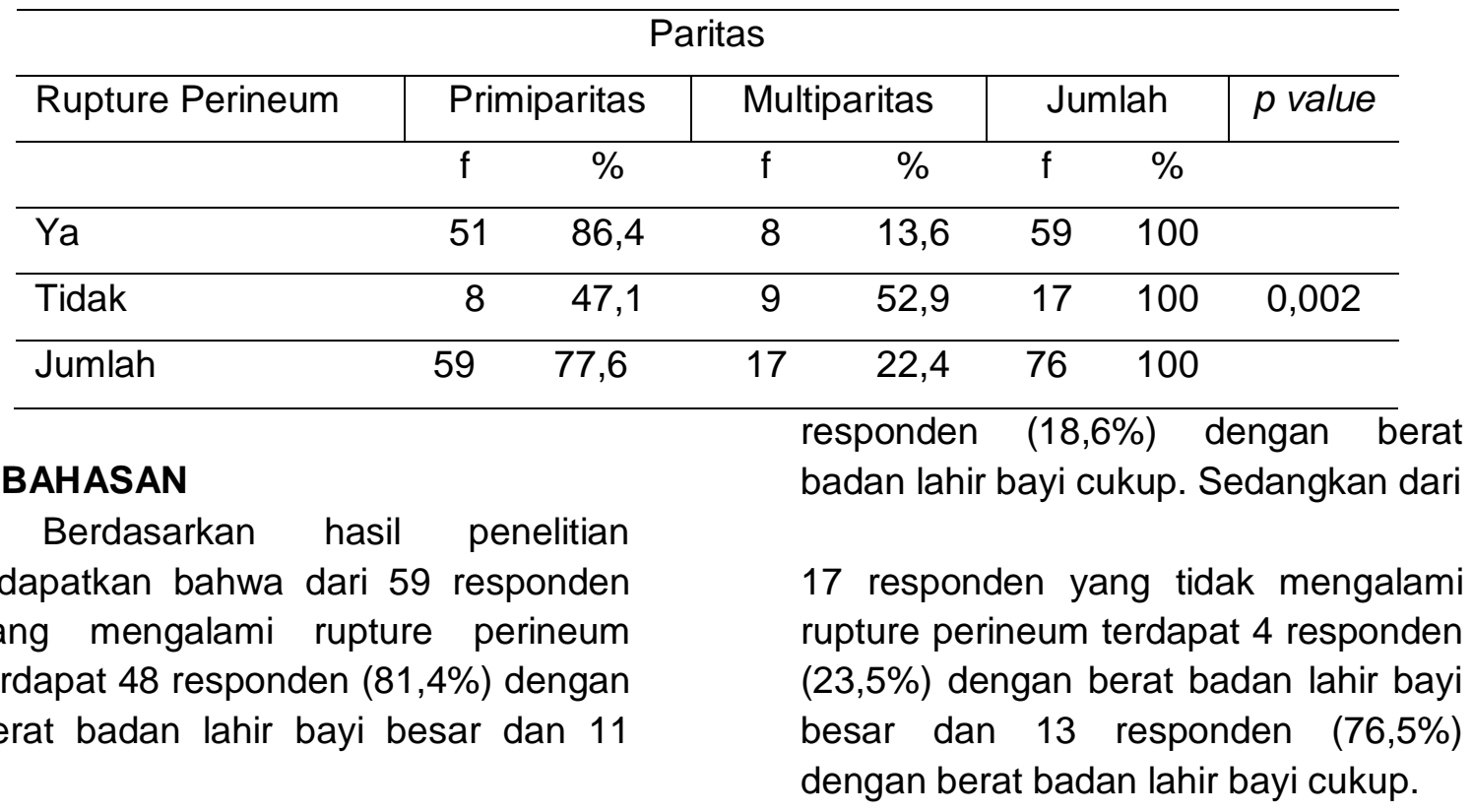


Hasil uji statistik chi-squre diperoleh $p$ value $0,000<0,05$ hal ini menunjukkan bahwa ada hubungan yang bermakna antara berat badan lahir dengan kejadian rupture perineum. Sehingga hipotesis terbukti secara statistik.

Hasil ini sejalan dengan penelitian Linda (2009) yang menyatakan terdapat hubungan berat badan bayi baru lahir dengan derajat ruptur perineum pada Persalinan Normal di Rumah Sakit Umum Daerah Kota Surakarta, Hasil penelitiannya menunjukkan ada hubungan bermakna antara berat badan bayi baru lahir dengan ruptur perineum dengan $p$ Value 0,003.

Berdasarkan hasil penelitian didapatkan bahwa dari 59 responden yang mengalami rupture perineum terdapat 51 responden $(86,4 \%)$ dengan memiliki jarak kelahiran beresiko dan 8 responden (13,6\%) dengan memiliki jarak kelahiran tidak beresiko. Sedangkan dari 17 responden yang tidak mengalami rupture perineum terdapat 7 responden $(41,2 \%)$ dengan memiliki jarak kelahiran beresiko dan 10 responden $(58,8 \%)$ dengan memiliki jarak kelahiran tidak beresiko.

Dari hasil uji statistik chi-squre diperoleh $p$ value $0,000<0,05$ ini menunjukkan bahwa ada hubungan yang bermakna antara jarak kelahiran dengan kejadian rupture perineum. Sehingga hipotesis terbukti secara statistik.

Hasil ini sejalan dengan penelitian Nurulichayang menyatakan ada hubungan yang bermakna antara jarak kehamilan dengan kejadian rupture perineum pada ibu bersalin dengan $P$ value $=0,038 \alpha \leq 0,05$

Dari hasil penelitian didapatkan bahwa dari 59 responden yang mengalami rupture perineum terdapat
51 responden $(86,4 \%)$ dengan memiliki primiparitas dan 8 responden $(13,6 \%)$ dengan memiliki multiparitas. Sedangkan dari 17 responden yang tidak mengalami rupture perineum terdapat 8 responden $(47,1 \%)$ dengan memiliki primiparitas dan 9 responden $(52,9 \%)$ dengan memiliki multiparitas.

Dari hasil uji statistik chi-squre diperoleh $p$ value $0,002<0,05$ ini menunjukkan bahwa ada hubungan yang bermakna antara paritas dengan kejadian rupture perineum. Sehingga hipotesis terbukti secara statistik.

Hasil penelitian ini sesuai dengan penelitian sebelumnya oleh Endriani (2012) yaitu dari hasil uji Chi Square menunjukkan nilai $P=0,001$ yang berarti $\mathrm{P}<0,05$ bahwa ada hubungan antara paritas dengan kejadian robekan perineum

\section{KESIMPULAN}

1. Ada hubungan berat badan lahir dengan kejadian rupture perineum dengan $p$ value $=0.000$.

2. Ada hubungan jarak kelahiran dengan kejadian rupture perineum dengan $p$ value $=0.000$.

3. Ada hubungan paritas dengan kejadian rupture perineum dengan $p$ value $=0.002$

\section{DAFTAR PUSTAKA}

Dinas Kesehaatan Kabupaten OKU. 2014. Destiati, Lisa dan Fitria Prabandari. 2010. Hubungan Antara Berat Badan Bayi Baru Lahir Dan Paritas Dengan Rupture Perineum Pada Persalinan Spontan Di RSIA Bunda Arif Purwokerto.

http//:jurnal.kti.kebidanan.ac.id. Diakses tanggal 18 Januari 2016

Endriani. (2012). Hubungan Umur, Paritas dan Berat Bayi Lahir Dengan Kejadian Laserasi Perineum(Di 
Bidan Praktek Swasta Hj. Sri Wahyuni,

S.SiT).http://digilib.unimus.ac.id, 03 Januari 2016

Kementerian Kesehatan Republik Indonesia. 2014. Profil Kesehatan Indonesia Tahun 2013. Jakarta: Kementerian Kesehatan Republik Indonesia.

Kementerian Kesehatan Republik Indonesia. 2014. Pusat Data Dan Informasi. Jakarta Selatan

Kurniati, dkk. 2011. Asuhan Kebidanan II (Persalinan). Yogyakarta : Rohima Press.

Linda. (2009). Hubungan Berat Badan Bayi Baru Lahir dengan Derajat Ruptur Perineum pada Persalinan Normal di Rumah Sakit Umum Daerah Kota Surakarta.Jurnal Kesehatan

Manuaba, Ida Ayu Chandranita. 2011. IImu Kebidanan, Penyakit Kandungan dan Keluarga Berencana untuk Pendidikan Bidan. Jakarta: EGC.

Mochtar, Rustam. 2012. Sinopsis Obstetri. Jakarta : EGC.

Notoatmodjo, Soekidjo. 2012. Metodologi Penelitian Kesehatan. Jakarta: Rineka.

Noviatri, Syarifah. 2015. Hubungan Berat Lahir Bayi Dengan Kejadian Rupture Perineum Pada Persalinan Normal Primipara Di RSUD Dr. Soedirman Kebumen.

Nurulicha. 2019. Faktor-Faktor yang Berhubungan dengan Kejadian Ruptur Perineum pada Ibu Bersalin. STIKes Mitra RIA Husada, Jakarta

Oxorn, Harry dan William R Forte. 2010. Patologi Dan Fisiologi Persalinan. Yogyakarta : Yayasan Essentia Medica.
Prawirohardjo, Sarwono. 2011. IImu Kebidanan. Jakarta: PT. Bina Pustaka Sarwono Prawirohardjo.

Rosmawar, Cut. 2013. Faktor-Faktor Yang Mempengaruhi Laserasi Pada Persalinan Normal Di Puskesmas Tanah Jambo Aye Panton Labu. http//: jurnal.kti.kebidanan.laserasi.ac.id Diakses tanggal 19 Februari 2016.

Sondakh, J S. Jenny. 2013. Asuhan Kebidanan Persalinan Dan Bayi Baru Lahir. Jakarta: Erlangga.

Saifuddin, Abdul Bari. 2011. Buku Acuan Nasional Pelayanan Kesehatan Maternal dan Neonatal. Jakarta : PT. Bina Pustaka Sarwono Prawirohardjo.

Saputra,Wiko Dan Hida Nurizka. 2013. Arah dan Strategi Kebijakan Penurunan AKI, AKB, AKABA, di Indonesia. Jakarta : Prakarsa Policy Papers/ Public Policy.

Shofiyani, Fathus. 2013. Hubungan Berat Badan Bayi Baru Lahir Dengan Rupture Perineum Spontan Pada Penatalaksanaan Kala II Persalinan Normal.

Sujiyatini, dkk. 2011. Asuhan Kebidanan II (Persalinan. Yogyakarta : Rohima Press.

Sumantri, Arif. 2013. Metodologi Penelitian Kesehatan. Jakarta : Kencana Prenada Media Group.

Sulistyawati, Ari dan Esti Nugraheny. 2011. Asuhan Kebidanan Pada lbu Bersalin. Jakarta: Salemba Medika.

Yongky, dkk. 2012. Asuhan Pertumbuhan Kehamilan, Persalinan, Neonatus, Bayi dan Balita.Yogyakarta: Mulia Medika. 